\title{
Genetic Diversity Among Endangered Pony Breeds in India: Need for Conservation
}

\author{
Ashok Gupta \\ National Research Centre on Equines, Sirsa Road, Hisar, Haryana, India \\ "Corresponding author: Ashok Gupta, National Research Centre on Equines, Sirsa Road, Hisar, Haryana, India, Tel: +91-1662-276748; E-mail: \\ akguptanrce@gmail.com
}

Received date: March 17, 2015; Accepted date: March 19, 2015; Published date: March 27, 2015

Copyright: (C) 2015 Gupta A. This is an open-access article distributed under the terms of the Creative Commons Attribution License, which permits unrestricted use, distribution, and reproduction in any medium, provided the original author and source are credited.

\section{Editorial}

Demand of equines throughout the world has decreased during the last few decades mainly due to their lesser work utility. In India also, population of horse and pony breeds has also decreased continuously from 1.50 million to 6.10 million during the last five decade (Livestock Census 2007) which has placed all the four registered pony breeds, namely Zanskari, Spiti, Manipuri and Bhutia into endangered breed category [1]. Animals of each breed are available in small number in different pockets throughout their home tracts. Manipuri pony is believed to be the oldest pony breed in world to be used as "Polo Pony" and at present, its total population in its home tract is around 400 to 1218 only. Exact population of true to breed animals of this breed is not yet clear due to lack of proper breed recording system. Same is the fate of other pony breeds namely Zanskari, Bhutia and Spiti In their home tracts. These pony breeds have acquired some unique characteristics which have enabled them to adopt themselves in the harsh climate and difficult terrains in their home tracts. These ponies are known for their sturdiness, stamina, speed on hilly and difficult terrains, high disease resistance, surefooted animals, and used mainly for riding and as pack animals in cold hilly regions. Zanskari pony is considered the hardiest amongst all the pony breeds and can work in the extremes of altitude and temperature. In view of their unique characteristics, it is an important issue for conservation biologists to conserve these breeds as future requirements of these breeds is not known.

It is well established that populations that have reduced in their demographic sizes, commonly show decreased genetic diversity among them [2-6]. Maintenance of adequate genetic diversity among animals of individual breed or species is quite important for the existence of that breed or species. Further continuous decline in populations can lead to demographic bottlenecks which may promote inbreeding depression $[7,8]$ and hinder a population's ability to adapt to environmental charges $[9,10]$. All such conditions are expected to increase a population's risk of extinction $[11,12]$.

Demographically all the four Indian pony breeds has decreased appreciably but high genetic diversity in terms of allelic richness and heterozygosity, has been observed in them [13-16] which is contrary to the common observations [2-8]. Maintenance of high genetic diversity in these pony breeds could possibly be either due to segregation of small animal clusters of individual breed in different pockets in their home tracts or due to selective breeding strategies adopted by local breeders in the recent past $[17,18]$. Though Spiti and Zanskari resemble closely to each other but animals of both the breeds have high genetic diversity among them also [16] which seems to be good enough for adapting suitable breeding policies for conservation of all the endangered pony breeds. Question of maintaining this genetic diversity in future is also quite important as further decline in overall population of each breed can lead to complete loss of these breeds. It is pertinent that if timely suitable conservation strategies are not implemented than these breeds may become an extinct breeds in near future.

\section{References}

1. Gupta AK, Chauhan M, Bhardwaj A, Tandon SN (2012) Microsatellite markers based genetic diversity and bottleneck studies in Zanskari pony. Gene 499: 357-361.

2. O’Brien SJ (1994) Genetic and phylogenetic analyses of endangered species. Ann Rev Genet 28: 467-489.

3. Vrijenhoek RC (1994) Genetic diversity and fitness in small populations. In: Conservation Genetics. Loeschcke V, Tomiuk J, Jain SK (eds) Birkhauser Verlag, Basel pp: 37-54.

4. Mundy NI, Winchell CS, Burr T, Woodruff DS (1997) Microsatellite variation and microevolution in the critically endangered San Clement Island loggerhead shrike (Lanius ludovicianus mearnsi). Proc Royal Soc London Series B 264: 869-875.

5. Gibbs HL, Prior K, Parent C (1998) Characterization of DNA microsatellite loci from a threatened snake: the eastern Massasauga rattlesnakes (Sistrurus c. catenatus) and their use in population studies. J Hered 89: 169-173.

6. Spencer CC, Neigel JD, Leberg PL (2000) Experimental evaluation of the usefulness of microsatellite DNA for detecting demographic bottlenecks. Mol Ecol 9: 1517-1528.

7. Nei M, Maruyama T, Chakraborty R (1975) Bottleneck effect and genetic variability in populations. Evolution 29: 1-10.

8. Frankham R (1995) Conservation genetics. Ann Rev Genet 29: 305-327.

9. Frankham R, Lees K, Montgomery ME, Englan PR, Lowe EH, et al. (1999) Do populations size bottlenecks reduce evolutionary potential? Anim Conserv 2: 255-260.

10. Hale KA, Briskie JV (2007) Decreased immunocompetence in a severly bottlenecked population of an endemic New Zealand bird. Anim Conserv 10: 2-10.

11. Frankel OH, Soule ME (1981) Conservation and Evolution. Cambridge University Press.

12. Saccheri I, Kuussaari M, Kankare M, Vikman P, Fortelius W, et al. (1998) Inbreeding and extinction in a butterfly meta population. Nature 392: 491-494.

13. Gupta AK, Chauhan M, Tandon SN, Sonia (2005) Genetic diversity and bottleneck studies in the Marwari horse breed. J Genet 84: 295-301.

14. Gupta AK, Tandon SN, Pal Y, Bhardwaj A, Chauhan M (2012) Phenotypic characterization of Indian horse breeds - A comparative study. AGRI 50: 49-58.

15. Gupta AK, Chauhan M, Bhardwaj A (2013) Genetic diversity and bottleneck studies in endangered Bhutia and Manipuri pony breeds. Mol Biol Rep 40: 6935-6943.

16. Gupta AK, Chauhan M, Bhardwaj A, Gupta N, Gupta SC, et al. (2014) Comparative Genetic Diversity Analysis among Six Indian Breeds and English Thoroughbred Horses. Livest Sci 163: 1-11. 
Citation: Gupta A (2015) Genetic Diversity Among Endangered Pony Breeds in India: Need for Conservation. J Biodivers Endanger Species 3: e124. doi:10.4172/2332-2543.1000e124

Page 2 of 2

17. Katoch S, Dogra PK, Thakur YP, Gupta K (2004) Phenotypic characterization of Spiti horse in its breeding tract-body measurements. Centaur 20: 45-48.
18. Pal Y, Legha RA, Thakur YP, Gupta AK, Singh RK (2011) SocioEconomic status of spiti horse owners vis-a-vis horse management in native tract. Vet Pract 12: 73-76. 